\title{
New records of calyptrate dipterans (Fanniidae, Muscidae and Sarcophagidae) associated with the decomposition of domestic pigs in Brazil
}

\author{
Rodrigo Rocha Barbosa, Cátia Antunes de Mello-Patiu, Rubens Pinto de Mello, \\ Margareth Maria de Carvalho Queiroz/+
}

Laboratório de Transmissores de Leishmaniose, Setor de Entomologia Médica e Forense, Instituto Oswaldo Cruz-Fiocruz, Av. Brasil 4365, 21045-900 Rio de Janeiro, RJ, Brasil

The calyptrate dipterans are the most important decomposers of human cadavers. Knowledge of their species and distribution are of great importance to forensic entomology, especially because of the enormous diversity in Brazil. Carcasses of domestic pigs (Sus scrofa, $L$ ) were the experimental models used to attract calyptrates of forensic interest during the winters of 2006 and 2007 and the summers of 2006 and 2008. A total of 24,423 specimens from 44 species were collected (19 Muscidae, 2 Fanniidae and 23 Sarcophagidae), three of which were new records of occurrence and 20 of which were new forensic records for the state of Rio de Janeiro. Fourteen of these species were newly identified as forensically important in Brazil.

Key words: forensic entomology - carcasses - calyptrate dipterans - Rio de Janeiro

Dipterans are the main insects involved in the decomposition of human cadavers and animal carcasses when exposed to open environments (Keh 1985, Smith 1986, Catts \& Haskell 1991, Oliveira-Costa 2008). Some of them use organic matter of animal origin for the development of their immature forms (Souza \& Linhares 1997). This behaviour of these insects is of great importance in forensic entomology because the developmental period of the immature forms is used as a basis for calculating the post-mortem interval (Greenberg 1991, Oliveira-Costa \& Mello-Patiu 2004).

Many species of calyptrate dipterans use carcasses of animals and human corpses to obtain protein for ovarian development or as a mating site (Smith 1986, Souza \& Linhares 1997, Carvalho et al. 2000). Therefore, it is necessary to know the species involved in the decomposition of animal carcasses and their geographical distribution.

In Brazil, there are few studies listing fly species associated with animal decomposition. Difficulties in identifying necrophagous calyptrate dipterans and the lack of taxonomic experts have become barriers in relation to this matter. Thus, the purpose of this study was to identify the species of calyptrate dipterans of the families Muscidae, Sarcophagidae and Fanniidae involved in the decomposition process of domestic pig carcasses in the city of Rio de Janeiro.

Financial support: PAPES V, CNPq

+ Corresponding author: mmcqueiroz@ioc.fiocruz.br

Received 13 April 2009

Accepted 22 July 2009
The experiment was carried out on the Fiocruz campus $\left(22^{\circ} 51^{\prime} 06^{\prime \prime} \mathrm{S} 43^{\circ} 14^{\prime} 27^{\prime \prime} \mathrm{W}\right)$ in the metropolitan area of Rio de Janeiro. Three areas with distinct physiographic characteristics were chosen for the experiments, each different from the other in terms of luminosity, vegetation and movement of people. One domestic pig carcass (Sus scrofa Linnaeus, 1758) weighing approximately $15 \mathrm{~kg}$ was used in each area to attract the insects. The pigs were sacrificed with a blow to the head and immediately placed inside the traps. These traps were composed of a metal, pyramid-shaped structure covered with a black cotton cloth, with a strip of white nylon along its lower rim for luminosity and ventilation. At the top of the pyramid, there was an insect pipe collector with a central window made of thin nylon to allow air and light into the pipe (Figure). The flies trapped inside the pipe were taken to the laboratory where they were identified at the family level and frozen at $-17^{\circ} \mathrm{C}$.

Identification keys were used to segregate the species according to Carvalho and Couri (2002), Carvalho et al. (2002), Couri and Carvalho (2002), Couri (2005) and Carvalho and Mello-Patiu (2008). The collections were carried out daily during four distinct periods: January 25, 2006-February 22, 2006 (summer), August 29, 2006September 21, 2006 (winter), August 15, 2007-August 27, 2007 (winter) and January 16, 2008-January 30, 2008 (summer). Muscids were collected and identified in all four experiments, while fanniids and sarcophagids were identified only in the two experiments during 2007 and 2008. In the present analysis, we considered that a species had a forensic record when it was caught in association with either human corpses or domestic pig carcasses (Oliveira-Costa 2008).

A total of 24,423 specimens from 44 species (19 Muscidae, 2 Fanniidae and 23 Sarcophagidae) were collected. Table shows the species list and highlights the new records of occurrence: new forensic records for Bra- 


\section{TABLE}

Absolute abundance, records of occurrence and forensic records of the species associated with the decomposition of domestic pigs in Brazil and in the state of Rio de Janeiro

\begin{tabular}{|c|c|c|c|c|c|c|c|c|}
\hline \multirow[b]{2}{*}{ Species } & \multicolumn{2}{|c|}{ Winter } & \multicolumn{2}{|c|}{ Summer } & \multirow[b]{2}{*}{$\mathrm{n}$} & \multirow[b]{2}{*}{ NRORJ } & \multirow[b]{2}{*}{ NFRRJ } & \multirow[b]{2}{*}{ NFRBr } \\
\hline & 2006 & 2007 & 2006 & 2008 & & & & \\
\hline \multicolumn{9}{|l|}{ Muscidae } \\
\hline Atherigona orientalis Schiner, 1868 & $\mathrm{x}$ & $\mathrm{x}$ & $\mathrm{x}$ & $\mathrm{x}$ & 7,310 & & & \\
\hline Biopyrellia bipuncta (Wiedemann, 1830) & & & $\mathrm{x}$ & & 2 & & $\mathrm{x}$ & \\
\hline Brontaea normata (Bigot, 1885) & $\mathrm{x}$ & $\mathrm{x}$ & $\mathrm{x}$ & $\mathrm{x}$ & 195 & & $\mathrm{x}$ & $\mathrm{x}$ \\
\hline Brontaea sp. & $\mathrm{x}$ & & $\mathrm{x}$ & & 26 & & $\mathrm{x}$ & $\mathrm{x}$ \\
\hline Cyrtoneurina sp. & $\mathrm{x}$ & & $\mathrm{x}$ & & 20 & & $\mathrm{x}$ & \\
\hline Cyrtoneuropsis conspersa (Stein, 1911) & & & & $\mathrm{x}$ & 2 & $\mathrm{x}$ & $\mathrm{x}$ & $\mathrm{x}$ \\
\hline Graphomya maculata (Scopoli, 1763) & $\mathrm{x}$ & $\mathrm{x}$ & $\mathrm{x}$ & $\mathrm{x}$ & 221 & $\mathrm{x}$ & $\mathrm{x}$ & $\mathrm{x}$ \\
\hline Limnophora deleta (Wulp, 1896) & & & & $\mathrm{x}$ & 28 & $\mathrm{x}$ & $\mathrm{x}$ & $\mathrm{x}$ \\
\hline Morelia couriae Pamplona, 1986 & & & $\mathrm{x}$ & & 4 & & & \\
\hline Morelia humeralis (Stein, 1918) & & $\mathrm{x}$ & & & 2 & & $\mathrm{x}$ & \\
\hline Morelia ochricornis Wiedemann, 1830 & $\mathrm{x}$ & $\mathrm{x}$ & $\mathrm{x}$ & $\mathrm{x}$ & 59 & & $\mathrm{x}$ & $\mathrm{x}$ \\
\hline Musca domestica Linnaeus, 1758 & $\mathrm{x}$ & $\mathrm{x}$ & $\mathrm{x}$ & $\mathrm{x}$ & 225 & & & \\
\hline Myospila pallidicornis (Bigot, 1887) & $\mathrm{x}$ & & $\mathrm{x}$ & & 93 & & $\mathrm{x}$ & $\mathrm{x}$ \\
\hline Neomuscina sp. 1 & $\mathrm{x}$ & & $\mathrm{x}$ & & 3 & & $\mathrm{x}$ & $\mathrm{x}$ \\
\hline Neomuscina sp. 2 & & & & $\mathrm{x}$ & 21 & & $\mathrm{x}$ & $\mathrm{x}$ \\
\hline Ophyra aenescens (Wiedemann, 1830) & $\mathrm{x}$ & $\mathrm{x}$ & $\mathrm{x}$ & $\mathrm{x}$ & 6,063 & & & \\
\hline Ophyra albuquerquei Lopes, 1985 & $\mathrm{x}$ & $\mathrm{x}$ & $\mathrm{x}$ & $\mathrm{x}$ & 37 & & $\mathrm{x}$ & \\
\hline Ophyra chalcogaster (Wiedemann, 1824) & $\mathrm{x}$ & $\mathrm{x}$ & $\mathrm{x}$ & $\mathrm{x}$ & 1,002 & & & \\
\hline Synthesiomyia nudiseta (Wulp, 1883) & $\mathrm{x}$ & $\mathrm{x}$ & $\mathrm{x}$ & $\mathrm{x}$ & 3,736 & & & \\
\hline \multicolumn{9}{|l|}{ Fanniidae } \\
\hline Fannia pusio (Wiedemann, 1830) & & $\mathrm{x}$ & & $\mathrm{x}$ & 3,114 & & & \\
\hline Fannia flavicincta (Stein, 1904) & & $\mathrm{x}$ & & $\mathrm{x}$ & 108 & & $\mathrm{x}$ & $\mathrm{x}$ \\
\hline \multicolumn{9}{|l|}{ Sarcophagidae } \\
\hline Helicobia aurescens Townsend, 1927 & & $\mathrm{x}$ & & $\mathrm{x}$ & 7 & & $\mathrm{x}$ & \\
\hline Helicobia pilipleura Lopes, 1939 & & $\mathrm{x}$ & & & 5 & & $\mathrm{x}$ & $\mathrm{x}$ \\
\hline Oxysarcodexia amorosa (Schiner, 1868) & & $\mathrm{x}$ & & $\mathrm{x}$ & 130 & & & \\
\hline Oxysarcodexia avuncula (Lopes, 1933) & & $\mathrm{x}$ & & $\mathrm{x}$ & 5 & & & \\
\hline Oxysarcodexia diana (Lopes, 1933) & & $\mathrm{x}$ & & $\mathrm{x}$ & 132 & & & \\
\hline Oxysarcodexia fluminensis Lopes, 1946 & & $\mathrm{x}$ & & $\mathrm{x}$ & 200 & & & \\
\hline Oxysarcodexia intona (Curran \& Walley, 1934) & & $\mathrm{x}$ & & $\mathrm{x}$ & 13 & & & \\
\hline Oxysarcodexia modesta Lopes, 1946 & & $\mathrm{x}$ & & & 1 & & & \\
\hline Oxysarcodexia parva Lopes, 1946 & & $\mathrm{x}$ & & $\mathrm{x}$ & 6 & & & \\
\hline Oxysarcodexia simplicoides (Lopes, 1933) & & $\mathrm{x}$ & & $\mathrm{x}$ & 14 & & $\mathrm{x}$ & $\mathrm{x}$ \\
\hline Oxysarcodexia thornax (Walker, 1849) & & $\mathrm{x}$ & & $\mathrm{x}$ & 573 & & & \\
\hline Oxysarcodexia timida (Aldrich, 1916) & & $\mathrm{x}$ & & $\mathrm{x}$ & 93 & & & \\
\hline Oxysarcodexia xanthosoma Aldrich, 1916 & & $\mathrm{x}$ & & $\mathrm{x}$ & 4 & & $\mathrm{x}$ & $\mathrm{x}$ \\
\hline Peckia (Euboettcheria) collusor (Curran \& Walley, 1934) & & $\mathrm{x}$ & & $\mathrm{x}$ & 18 & & & \\
\hline Peckia (Pattonella) intermutans (Thomson, 1869) & & $\mathrm{x}$ & & $\mathrm{x}$ & 17 & & & \\
\hline Peckia (Peckia) chrysostoma (Wiedemann, 1830) & & $\mathrm{x}$ & & $\mathrm{x}$ & 68 & & & \\
\hline Ravinia belforti (Prado \& Fonseca, 1932) & & $\mathrm{x}$ & & $\mathrm{x}$ & 245 & & & \\
\hline Sarcodexia lambens (Wiedemann, 1830) & & $\mathrm{x}$ & & $\mathrm{x}$ & 79 & & & \\
\hline Sarcofahrtiopsis cuneata (Townsend, 1935) & & $\mathrm{x}$ & & $\mathrm{x}$ & 5 & & $\mathrm{x}$ & $\mathrm{x}$ \\
\hline Sarcophaga (Bercaea) africa (Wiedemann, 1824) & & & & $\mathrm{x}$ & 2 & & & \\
\hline Sarcophaga (Liopygia) ruficornis (Fabricius, 1794) & & & & $\mathrm{x}$ & 1 & & & \\
\hline Tytanogripa (Cucullomyia) larvicida (Lopes, 1935) & & $\mathrm{x}$ & & & 1 & & $\mathrm{x}$ & \\
\hline Tricharea (Sarcophagula) occidua (Fabricius, 1794) & & $\mathrm{x}$ & & $\mathrm{x}$ & 533 & & & \\
\hline
\end{tabular}

n: absolute abundance; NFRBr: new forensic record in Brazil; NFRRJ: new forensic record in state of Rio de Janeiro; NRORJ: new record of occurrence in RJ.

zil and for the state of Rio de Janeiro (RJ). In this study, 14 species were recorded for the first time in association with decomposing domestic pig carcasses in Brazil and 20 for RJ. In addition, three muscid species not listed previously by Couri and Carvalho (2005) were new records for RJ: Cyrtoneuropsis conspersa (Stein), Graphomya maculata (Scopoli) and Limnophora deleta (Wulp).

In pioneer studies carried out by Oliveira-Costa and Lopes (2000) and Oliveira-Costa et al. (2001a, b), also in RJ, Ophyra aenescens (Wiedemann), Musca domestica 


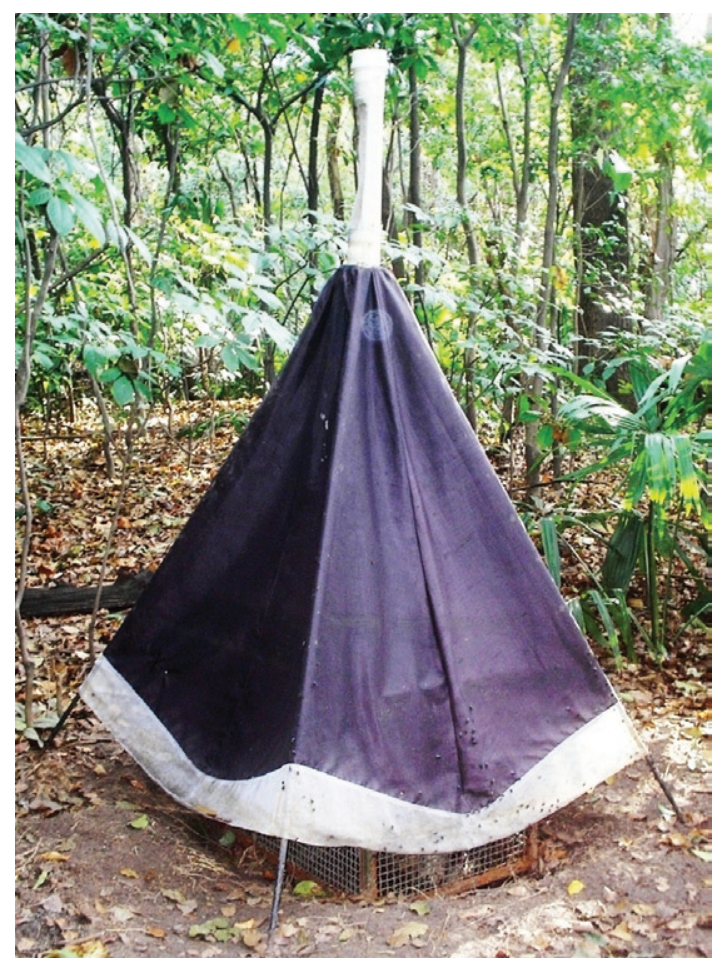

Trap model for capture of the calyptrate dipterans.

Linnaeus and Synthesiomyia nudiseta (Wulp) were the only Muscidae species associated with human corpses at a crime scene. However, among the sarcophagids, two species identified in those studies were not found in the present study: Oxysarcodexia terminalis (Wiedeman; Hybopygia terminalis) and Oxysarcodexia angrensis (Lopes). No other forensic entomological study in this region has been published so far.

Other papers listing calyptrate dipterans associated with the decomposition of human and animal carcasses, such as the one compiled by Oliveira-Costa (2008), have also been presented for different Brazilian states. Some species are commonly found in carcasses in different regions of Brazil; among the Muscidae, we can highlight Ophyra spp, S. nudiseta and M. domestica (MonteiroFilho \& Penereiro 1987, Moura et al. 1997, 2005, Carvalho et al. 2000, 2004, Marchiori et al. 2000, Carvalho \& Linhares 2001, Souza et al. 2008).

In this work, only two Fanniidae species were collected, but only Fannia pusio (Wiedemann) has a forensic record in Brazil (Monteiro-Filho \& Penereiro 1987, Carvalho et al. 2000, 2004, Moura et al. 2005, Souza et al. 2008).

The sarcophagids presented the greatest diversity of species in this study. The Oxysarcodexia, Peckia and Sarcodexia species are the most commonly collected in association with decomposing animals (Monteiro-Filho \& Penereiro 1987, Moura et al. 1997, 2005, Souza \& Linhares 1997, Carvalho et al. 2000, 2004, Carvalho \& Linhares 2001, Barros et al. 2008, Carvalho \& Mello-Patiu 2008).
The results presented here provide fundamental information concerning the geographical distribution of insect species of forensic importance and for the establishment of a specific data bank for future use in criminal investigations.

\section{ACKNOWLEDGMENTS}

To Dra. Márcia Souto Couri, Muscidae and Fanniidae specialist of the Department of Entomology of the Museu Nacional/UFRJ, and to Dr. José Mario d'Almeida, Department of General Biology, Universidade Federal Fluminense, for the great help in identifying some calyptrate dipterans.

\section{REFERENCES}

Barros RM, Mello-Patiu CA, Pujol-Luz JR 2008. Sarcophagidae (Insecta, Diptera) associados à decomposição de carcaças de Sus scrofa Linnaeus (Suidae) em área de cerrado do Distrito Federal, Brasil. Rev Bras Entomol 52: 606-609.

Carvalho CJB, Couri MS 2002. Muscidae (Diptera) of the Neotropical Region: taxonomy. In CJB Carvalho (ed.), Part I. Basal groups, Editora Universidade Federal do Paraná, Curitiba, p. 17-259.

Carvalho CJB, Mello-Patiu CA 2008. Key to the adults of the most common forensic species of Diptera in South America. Rev Bras Entomol 52: 390-406.

Carvalho CJB, Moura MO, Ribeiro PB 2002. Chave para adultos de dípteros (Muscidae, Fanniidae, Anthomyiidae) associados ao ambiente humano no Brasil. Rev Bras Entomol 46: 107-114.

Carvalho LML, Linhares AX 2001. Seasonality of insect successions and pig carcass decomposition on a natural forest area in Southeastern Brazil. J Forensic Sci 46: 604-608.

Carvalho LML, Thyssen PJ, Goff ML, Linhares AX 2004. Observations on the succession patterns of necrophagous insects on a pig carcass in an urban area of Southeastern Brazil. Forensic Med Toxicol 5: 33-39.

Carvalho LML, Thyssen PJ, Linhares AX, Palhares FAB 2000. A checklist of arthropods associated with pig carrion and human corpses in Southeastern Brazil. Mem Inst Oswaldo Cruz 95: 135-138.

Catts EP, Haskell NH 1991. Entomology and death: a procedural guide, Joyce's Print Shop, Clemson, 182 pp.

Couri MS 2005. An illustrated key to adult males of Neotropical Fannia Robineau-Desvoidy belonging to pusio sub-group (Diptera, Fanniidae). Braz J Biol 65: 625-629.

Couri MS, Carvalho CJB 2002. Muscidae (Diptera) of the Neotropical Region: taxonomy. In CJB Carvalho (ed.), Part II. Apical groups, Editora Universidade Federal do Paraná, Curitiba, p. 133-287.

Couri MS, Carvalho CJB 2005. Diptera Muscidae do estado do Rio de Janeiro (Brasil). Biota Neotropica 5: 205-222.

Greenberg B 1991. Flies as forensic indicators. J Med Entomol 28: 565-577.

Keh B 1985. Scope and applications of forensic entomology. Annu Rev Entomol 30: 137-154.

Marchiori CH, Silva CG, Caldas CIS, Almeida KGS, Teixeira FF, Linhares AX 2000. Dípteros muscóides associados com carcaça de suíno e seus parasitóides em área de pastagem e de mata em Goiás. Arq Bras Med Vet Zootec 67: 167-170.

Monteiro-Filho ELA, Penereiro JL 1987. Estudo da decomposição e sucessão sobre uma carcaça animal numa área do estado de São Paulo, Brasil. Rev Bras Biol 47: 289-295. 
Moura MO, Carvalho CJB, Monteiro-Filho ELA 1997. A preliminary analysis of insects of medical-legal importance in Curitiba, state of Paraná. Mem Inst Oswaldo Cruz 92: 269-274.

Moura MO, Monteiro-Filho ELA, Carvalho CJB 2005. Heterotrophic succession in carrion arthropod assemblages. Brazil Archiv of Biol Techn 48: 473-482.

Oliveira-Costa J 2008. Entomologia forense - quando os insetos são vestígios, $2^{a}$ ed., Millennium, Campinas, 420 pp.

Oliveira-Costa J, Lopes SM 2000. A relevância da entomologia forense para a perícia criminal na elucidação de um caso de suicídio. Entomol Vect 7: 203-209.

Oliveira-Costa J, Mello-Patiu CA 2004. Application of forensic entomology to estimate of the postmortem interval (PMI) in homicide investigations by the Rio de Janeiro Police Department in Brazil. Forensic Med Toxicol 5: 40-44.
Oliveira-Costa J, Mello-Patiu CA, Lopes SM 2001a. Dípteros muscóides associados com cadáveres humanos na cena da morte no estado do Rio de Janeiro - Brasil. Bol Mus Nac Zoo 464: 1-6.

Oliveira-Costa J, Mello-Patiu CA, Lopes SM 2001b. Influência de diferentes fatores na freqüência de dípteros muscóides em cadáveres humanos no Rio de Janeiro. Bol Mus Nac Zoo 470: 1-10.

Smith KGV 1986. A manual of forensic entomology, British Museum (Natural History), London, 205 pp.

Souza AM, Linhares AX 1997. Diptera and coleoptera of potential forensic importance in Southeastern Brazil: relative abundance and seasonality. Med Vet Entomol 11: 8-12.

Souza ASB, Kirst FD, Krüger RF 2008. Insects of forensic importance from Rio Grande do Sul state in Southern Brazil. Rev Bras Entomol 52: 641-646. 